\title{
Accounting Education research. Gaining the deserved recognition
}

\author{
José L. Arquero (arquero@us.es) \\ Editor de EDUCADE, Universidad de Sevilla, (España) \\ https://orcid.org/0000-0002-7086-8812 \\ http://dx.doi.org/10.12795/EDUCADE.2021.i12.01
}

Research in accounting education has been considered, in terms of research, the poor sister among the different sub-disciplines of accounting (accounting being already the poor sister among the disciplines related to economics and business). The way to assess the quality of a paper, based in the metrics of the journal in which it has been published and, sometimes, in the number of citations in other academic journals is not the best way to measure the relevance of this kind of academic outputs. The impact on classroom dialogue, as Sangster et al. (2015) highlight, is probably the most relevant one. For certain papers the most relevant should be the impact on education policies or curricular design (e.g. those papers dealing with objectives, etc.). As Chow et al. (2007) and Reinstein et al., (2011) note, practitioner or pedagogy-focused articles may significantly influence policy, practice, approaches to teaching, or educational materials with no explicit published cited work.

In any case, this does not seem to have discouraged the researchers who have continued to do what they considered to be the right thing and to focus on work of academic quality and practical relevance. The results, little by little, are rewarding this effort. If we pay attention to the metrics used to evaluate the quality of research (knowing in advance that they neither evaluate quality nor should they be used without correct interpretation), we can see the sustained improvement of the specific journals in the area over time.

According to Scimago Journal \& Country Rank (commonly known as the Scopus ranking) Accounting education, edited by Prof. Alan Sangster, moved from Q4 in accounting and Q4 education in 2009 to Q2 and Q1 respectively in 2020. Similarly, the Journal of Accounting Education, edited by Prof. Natalie T. Churik, moved from the lowest quartile in 2000 to a Q1 in 2020 in both categories (Accounting and Education)

The International Journal of Management Education, edited by Prof. Neil Marriott, although not entirely devoted to accounting publishes papers in our area. IJME also moved from the Q4, in year 2000, to a consistent Q2 kept in 2020 
in both Education and Organizational Behavior and Human Resource Management categories.

It is to be noted that Prof Sangster warning is still relevant (Sangster, 2013); the Social Sciences Citation Index doesn't adequately cover accounting as an area and this lack of cover is extreme in the case of accounting education: only one out of these three journals is fully covered by the SSCl: the IJME, which is ranked in the Q2, Education \& Educational Research, category.

There is still a long way to go. Let's hope that these journals, which are more than likely to be entering in good positions, will be included in the listings. Some of them are now covered in the Emerging Sources Citation Index, obtaining good positions in the alternative indicator recently developed by WoS, the Journal Citation Indicator (JCl); e.g. Accounting Education is ranked Q2 since 2017 to 2020. Step by step, the hard work of authors, editors and reviewers are gaining the deserved recognition, slowly, later than it should have been, but undoubtedly.

\section{References}

Chow, C. C., K. Haddad, G. Singh, and A. Wu. 2007. On using journal rank to proxy for an article's contribution or value. Issues in Accounting Education, 22 (39), 411 427.

Reinstein, A., Hasselback, J. R., Riley, M. E., \& Sinason, D. H. (2011). Pitfalls of using citation indices for making academic accounting promotion, tenure, teaching load, and merit pay decisions. Issues in Accounting Education, 26(1), 99-131.

Sangster, A. (2013). Invited Editorial: The effect of indexes, rankings and impact factors in accounting research and in accounting education in particular. Educade: revista de educación en contabilidad, finanzas y administración de empresas, (4), 1-4.

Sangster, A., Fogarty, T., Stoner, G., and Marriott, N. (2015). The impact of accounting education research. Accounting Education, 24(5), 423-444. 